\title{
METHODOLOGY
}

\section{An alkaline single-cell gel electrophoresis (comet) assay for environmental biomonitoring with native rodents}

\author{
Juliana da Silva ${ }^{1}$, Thales R.O. de Freitas ${ }^{1}$, Jorge R. Marinho ${ }^{1}$, Günter Speit ${ }^{2}$ and Bernardo Erdtmann ${ }^{1}$
}

\begin{abstract}
The main advantages of single-cell gel electrophoresis (SCG) are its applicability to any eukaryotic organism and cell type, its low cost and the short time required to obtain results. These properties make the SCG assay particularly useful in screening for environmental genotoxicity. The present study describes a modified version of this technique for use in field work with native rodents and examines some factors which influence the outcome of the assay. Wild rodents (Ctenomys torquatus, "tuco-tuco") from a region close to a strip coal mine and from a region with no coal mines were used. Animals from the coal mining region had significantly more DNA damage than those from the control area. The use of this SCG technique for direct sampling in the field should facilitate environmental genotoxicity studies with natural populations, without the need to remove the animals from their habitat or to sacrifice them.
\end{abstract}

\section{INTRODUCTION}

The alkaline single-cell gel electrophoresis (SCG) assay, a new procedure for evaluating DNA lesions (single strand breaks and alkali-labile sites), involves application of an electrical current to cells, which results in the transport of DNA fragments out of the nucleus. The image of DNA migration obtained resembles a comet with a head and a tail, hence the term comet assay (Klaude et al., 1996; Singh and Stephens, 1996). Since the DNA damage induced by toxic agents is often tissue- and cell-specific, SCG is very useful because it can detect DNA lesions in individual cells obtained under a variety of experimental conditions; the technique can also be used to evaluate DNA repair (Tice, 1995).

A significant advantage of the SCG assay is its applicability to any eukaryotic organism and cell type. Since the assay is also inexpensive and gives results within a few hours, it is appropriate for environmental monitoring. In addition to human peripheral blood lymphocytes exposed to different agents, both in vitro and in vivo (Collins et al., 1997), other cell types and organisms have also been tested with this assay (Petras et al., 1995; Tice, 1995; Verschaeve and Gilles, 1995; Sasaki et al., 1997a,b). In particular, native animals, especially small mammalian species, living in or close to polluted zones, have been used to detect hazardous pollution (Nascinbeni et al., 1991; Farbairn et al., 1995; Petras et al., 1995; Tice, 1995; Baker et al., 1996; Salagovic et al., 1996; Ralph et al., 1997).

Since Singh et al. (1988) published their description of the SCG assay, there has been rapid growth in the use of the comet assay. The small variations in the different steps of the technique reported by different authors have been reviewed (McKelvey-Martin et al., 1993; Farbairn et al., 1995).

In this report, we adapted the SCG assay for use in field work and assessed the factors that influence this assay using Ctenomys torquatus, a rodent endemic to southern Brazil (Freitas, 1995), to evaluate the influence of coal mining as an environmental hazard.

\section{MATERIAL AND METHODS}

Animals

Specimens of Ctenomys torquatus (OctodontidaeRodentia), a fossorial rodent with low vagility, were captured at two sites in southern Brazil: Pelotas, a region with no coal mine, was used as an external control, and Candiota, close to a strip coal mine. The two populations had the same karyotype $(2 \mathrm{n}=44$ and $\mathrm{FN}=72)$, indicating chromosomal uniformity (Freitas and Lessa, 1984). The rodents were captured in summer 1996, in the same week, one day per site. All of the animals were captured from 10 a.m. to 6 p.m.; seven rodents from Pelotas and 11 from Candiota were used (no more than one per burrow). Oneida Victor (number zero) traps with a rubber cover for fossorial rodents were set where fresh earth mounds were located. All animals, were anesthetized with Zoletil (Virbac, $8 \mathrm{mg} / \mathrm{kg}$ ) as soon as captured, prior to blood sampling, and were then returned to their habitat after recovering from the anesthesia.

${ }^{I}$ Departamento de Genética, Instituto de Biociências, UFRGS, Av. Bento Gonçalves, 9500, Caixa Postal 15053, 91501-970 Porto Alegre, RS, Brasil. Send correspondence to J.S. E-mail: juliana@if.ufrgs.br

${ }^{2}$ Universität Ulm, Abteilung Medizinische Genetik, D-89069 Ulm, Germany. 


\section{Blood samples}

Blood samples were collected from foot pricks of anesthetized animals, using heparinized capillaries. The samples were stored in Eppendorf tubes (blood + liquemine; Roche) on ice and protected from light until processed. Human blood samples collected on the same day under the same conditions served as an internal control for possible damage during manipulation or transport to the laboratory.

\section{Comet assay}

The comet assay (alkali method) was modified from that described by Singh et al. (1988) and took into account the observations of Hartmann and Speit (1995) and Tice (1995). Roughened microscope slides were dipped briefly into $1.5 \%$ hot $\left(60^{\circ} \mathrm{C}\right)$ normal melting agarose (NMA) prepared in phosphate-buffered saline (PBS). The slides were dried overnight at room temperature and then stored at $4^{\circ} \mathrm{C}$ until used. Each slide was coated with 300 $\mu \mathrm{l}$ of $1.0 \%$ NMA in PBS, as soon as the agarose had boiled, and then covered with a coverslip and transferred to a humidified box at $4^{\circ} \mathrm{C}$ for a least 5 min (slides used until 24 $\mathrm{h}$ maintained good quality) to allow the agarose to solidify. Subsequently, blood (7-10 $\mu \mathrm{l})$ mixed with $95 \mu \mathrm{l}$ of $0.75 \%$ low melting point agarose (LMA) (Gibco BRL) at $37^{\circ} \mathrm{C}$ was spread on the slide using a coverslip and then allowed to solidify at $4^{\circ} \mathrm{C}$ in a moist box. After removal of the coverslip, the slides were immersed in freshly prepared cold $\left(4^{\circ} \mathrm{C}\right)$ lysing solution $(2.5 \mathrm{M} \mathrm{NaCl}, 100 \mathrm{mM}$ EDTA, 10 $\mathrm{mM}$ Tris; $\mathrm{pH} 10-10.5 ; 1 \%$ Triton X-100 and 10\% DMSO added just before use) for at least $1 \mathrm{~h}$ and for up to four weeks.

All procedures up to the lysis were done in the field. Two slides per rodent were prepared. The slides were kept in lysing solution, packed and transported on ice to the laboratory. In addition, whole blood samples from rodents and humans were mixed with RPMI 1640 medium (1:10), and kept at $4^{\circ} \mathrm{C}$ during transport. This precaution allows the preparation of more slides in the laboratory if necessary.

The alkaline unwinding, electrophoresis and neutralization steps were performed as described by Hartmann and Speit (1995), with minor modifications. The slides were removed from the lysis solution and placed in the electrophoresis chamber, which was then filled with freshly made alkaline buffer $(300 \mathrm{mM} \mathrm{NaOH}$ and $1 \mathrm{mM}$ EDTA, pH 12.6). The cells were exposed to alkali for 30 min to allow for DNA unwinding and the expression of alkali-labile sites. Subsequently, the DNA was electrophoresed for $30 \mathrm{~min}$ at $300 \mathrm{~mA}$ and $25 \mathrm{~V}$ in an ice bath. All of the above steps (preparation of slides, lysis and electrophoresis) were conducted under red light or without direct light in order to prevent additional DNA damage. The main advantage of using weak alkali ( $\mathrm{pH}$ 12.6) in the electrophoresis step was the possibility of maintaining the sensitivity of the alkali assay $(\mathrm{pH}>13)$ in which the extended comet tails would be clearly distinguishable from the heads, and thus be easier to evaluate (Klaude et al., 1996).

In all cases, negative and positive controls were run using human blood. For the positive control, $200 \mu \mathrm{l}$ of whole blood was incubated for $2 \mathrm{~h}$ at $37^{\circ} \mathrm{C}$ with $50 \mu \mathrm{l}$ of methyl methanesulfonate (MMS; final concentrations of $8 \times 10^{-5} \mathrm{M}$ and $4 \times 10^{-5} \mathrm{M}$ ). The two concentrations were used to demonstrate different levels of damage and to ascertain the assay sensitivity.

After electrophoresis, the slides were placed in a horizontal position and washed three times ( $5 \mathrm{~min}$ each) with $0.4 \mathrm{M}$ Tris buffer, $\mathrm{pH} 7.5$, to neutralize the excess alkali. Finally, $70 \mu \mathrm{l}$ of ethidium bromide $(2 \mu \mathrm{g} / \mathrm{ml})$ was added to each slide, which was then covered with a coverslip, stored in a humidified box at $4^{\circ} \mathrm{C}$ and analyzed using a fluorescence microscope with a calibrated eyepiece. The slides maintained a good fluorescent image for at least four days.

Images of 50 randomly selected cells ( 25 cells from each of two replicate slides) were analyzed from each animal. Comet tail lengths (nuclear region + tail) were measured in arbitrary units. One unit was approximately $5 \mu \mathrm{m}$ at 200X magnification. The fluorescence microscope was equipped with a BP546/12-nm excitation filter and a 590$\mathrm{nm}$ barrier filter. Cells were also scored visually into five classes, according to tail size (from undamaged-0, to maximally damaged-4) (Figure 1) and a value was assigned to each comet according to its class. The final overall rating for the slide, DNA damage score, between 0 (completely undamaged) and 200 (maximum damage), was obtained by summation (Collins et al., 1995, 1997). Apoptotic cells were observed (Figure 1F) but not evaluated, since they represented dead cells (Olive et al., 1993; Speit and Hartmann, 1996).

The statistical evaluation was performed using twotailed Student's $t$-test. A difference at $\mathrm{P}<0.05$ was considered statistically significant.

\section{RESULTS AND DISCUSSION}

The normal appearance of the cell and comet structures changed depending on the duration of storage in the lysing solution. The slides could be stored for at least two weeks in cold lysing solution without affecting the results, but the cell quality was better the sooner electrophoresis was performed. After four weeks, the normal cells and the comets showed reduced definition with fading at the edges.

RPMI 1640 medium was a good option for transporting blood samples to the laboratory. The cells remained in good condition for up to four days with no significant change compared to cells prepared on the day of collection.

There was no significant difference in the mean of total image length in the cells of animals between the coal mining region and the internal and external controls (Figure 2), although rodents from Pelotas and Candiota had a 

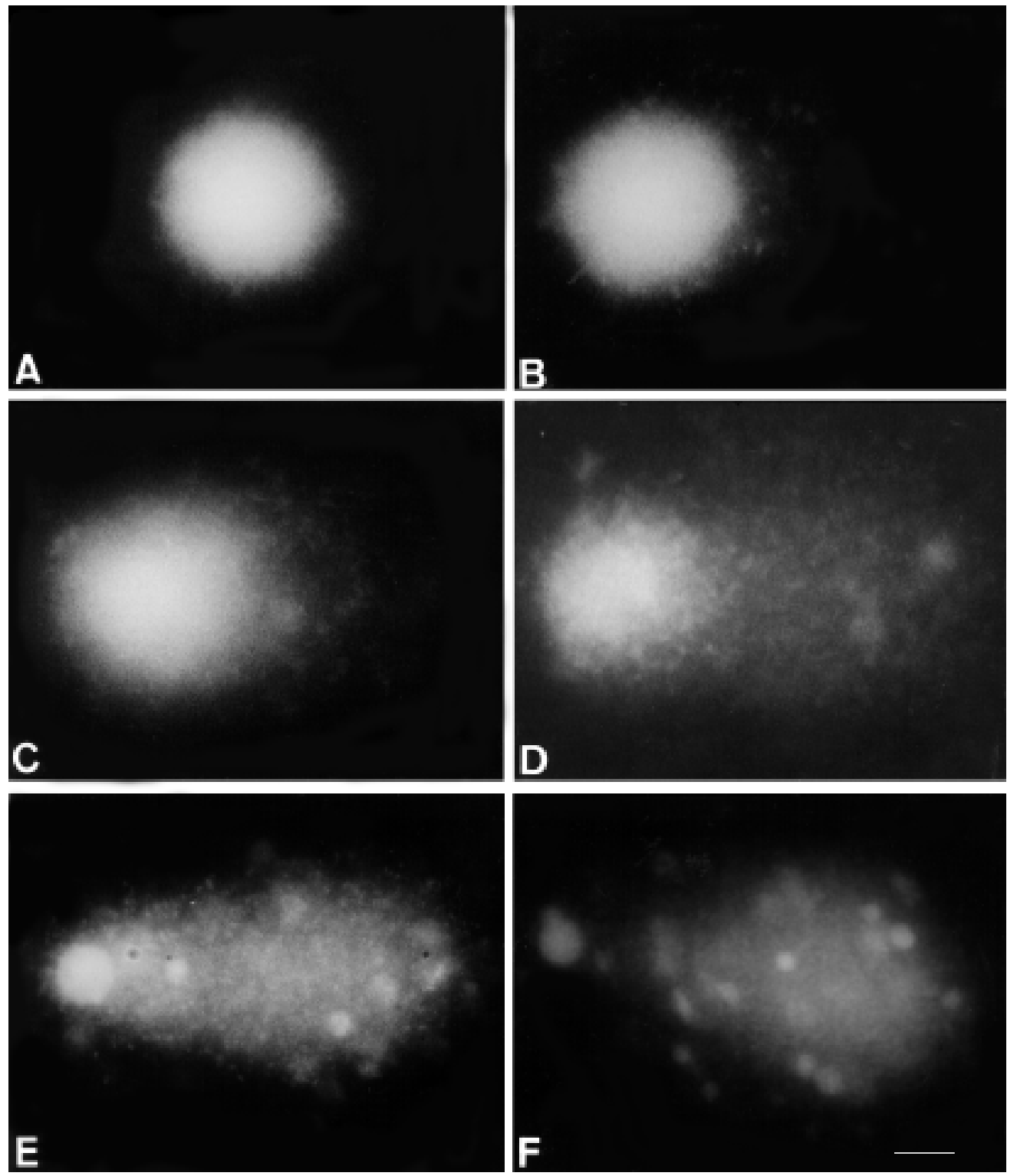

Figure 1 - Photomicrographs showing the classification of Ctenomys torquatus blood cells in the comet assay. A. Class 0, undamaged; $\mathbf{B}$, class $1 ; \mathbf{C}$, class 2; D, class 3; E, class 4, maximum damage; $\mathbf{F}$, apoptotic cell. Bar $=10 \mu \mathrm{m}$.

mean tail length slightly superior to the internal control. Olive et al. (1992) discussed DNA migration as a parameter for DNA damage in neutral or alkaline assays, $\mathrm{pH} 12.3$. These authors discounted the usefulness of this measure based on the observation that the distance of DNA migration reached a plateau while the DNA tail:head ratio continued to increase.

There was significantly greater DNA damage score (arbitrary units) in the Candiota group than in the control groups (Figure 3). Similarly, animals from Pelotas (external control) had more damage than the human samples (internal control). This difference between external and internal controls may reflect the presence of some pollutants in Pelotas or of some inherent factor in this population. Similar results were observed with earth- worms (Verschaeve and Gilles, 1995), two species of tadpoles (Ralph et al., 1997), and bullheads and carp (Pandrangi et al., 1995), in which the external controls showed higher values than the internal controls. These results indicate that data obtained under laboratory conditions do not necessarily reflect those obtained in the field. In these studies, the SCG was sufficiently sensitive to detect naturally occurring levels of genotoxic agents.

The DNA damage at Candiota included almost half of the cells analyzed (48\%), whereas at Pelotas only $20 \%$ of the cells had "comet" cells, thus confirming the ability of coal and derivatives to cause genetic damage. Several studies have described coal-related problems and the subsequent effects. Thus, Srám et al. (1985) analyzed chro- 


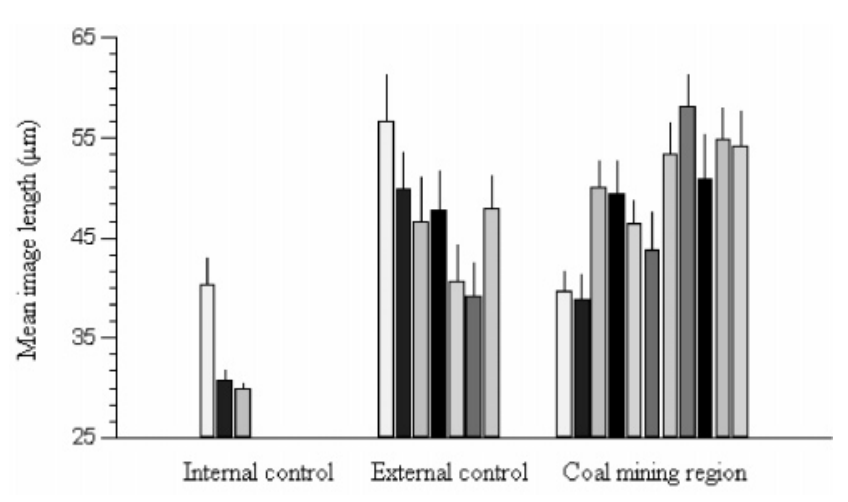

Figure 2 - Mean comet tail length $( \pm S D)$ in rodents from Pelotas (external control) and Candiota (coal mining region) and for human blood (internal control). Each column represents one animal.

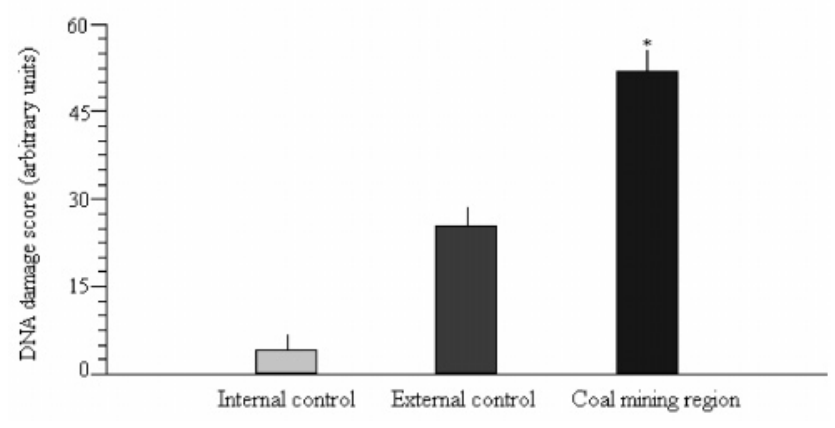

Figure 3 - Mean DNA damage score ( \pm SD) (arbitrary units) for rodents from Pelotas (external control) and Candiota (coal mining region) and for human blood (internal control). ${ }^{*} \mathrm{P}<0.05$ compared to Pelotas. Student's two-tailed $t$-test in both cases.

mosome aberrations in lymphocytes from open-cast mining workers engaged in stripping and digging operations, and Salagovic et al. (1996) used SCG to evaluate DNA damage in earthworms exposed to coke.

Coal contains polycyclic aromatic hydrocarbons (PAHs), the environmental behavior of which has been investigated for many years. Because of their toxicity, environmental persistence, and prevalence, PAHs and their metabolites bind to and disrupt the organization of DNA and RNA, which provides the basis for their tumorpromoting activity. For this reason, PAHs are listed by some environmental protection agencies as priority pollutants. However, analytical techniques used to quantify the levels of known pollutants do not provide insights into the biological hazards associated with pollution by these compounds (Verschaeve and Gilles, 1995).

Our results for the rodent $C$. torquatus indicate that coal-induced DNA damage is detectable by the SCG assay, and confirm the viability of this method in environmental biomonitoring in the field. The study of animals in their habitat and without the need to sacrifice them provides an ideal approach for environmental evaluation.

\section{ACKNOWLEDGMENTS}

This work was supported by CNPq, FAPERGS, FINEP and GENOTOX.

\section{RESUMO}

A mais importante vantagem do Ensaio Cometa é a possibilidade do seu uso em qualquer organismo e tipo celular. Além de ser barato e rápido, se obtem resultados em poucas horas. Devido a isto é que ele vem sendo recomendado como teste inicial para monitoramento genotóxico ambiental. Neste trabalho investigaram-se adaptações na técnica para trabalhos de campo, com o uso de roedores endêmicos de região de mineração de carvão. O organismo utilizado foi o Ctenomys torquatus, capturado em duas diferentes áreas: Pelotas (região sem mineração de carvão-controle) e Candiota (zona de mineração de carvão). Foi coletado sangue periférico de 18 roedores, que após marcação foram liberados. O sangue foi protegido da luz e mantido sob refrigeração, e processado in loco. As concentrações das agaroses e as condições alcalinas de lise e eletroforese foram modificadas a partir das metodologias sugeridas pelas revisões existentes. As amostras restantes foram mantidas em RPMI 1640 $(1: 10)\left(4^{\circ} \mathrm{C}\right)$ e pela nossa experiência podem ser utilizadas por até 4 dias. Foram analisadas 50 células por animal. As células foram classificadas de 0-4, segundo seu grau de lesão, além de serem medidas em unidades arbitrárias. Foi demonstrado aumento significante no nível de dano do DNA no grupo de Candiota $(\mathrm{P}<$ 0,05 - teste $t$ ), quando comparado com Pelotas. Ainda se demonstrou correlação entre o índice de danos e as medidas celulares. Estes resultados, neste estudo piloto, indicam que o carvão induz efeitos no DNA que são detectáveis através do Ensaio Cometa, o que indica a viabilidade deste teste para o biomonitoramento ambiental.

\section{REFERENCES}

Baker, R.J., Hamilton, M.J., Bussche, R.A.V.D., Wiggins, L.E., Sugg, D.W., Smith, M.H., Lomakin, M.D., Gaschak, S.P., Bundova, E.G., Rudenskaya, G.A. and Chesser, R.J. (1996). Small mammals from the most radioactive sites near the Chernobyl nuclear power plant. $J$. Mammal. 77: 155-170.

Collins, A., Ai-guo, M. and Duthie, S.J. (1995). The kinetics of repair of oxidative DNA damage (strand breaks and oxidised pyrimidines) in human cells. Mut. Res. 336: 69-77.

Collins, A., Dusinská, M., Franklin, M., Somorovská, M., Petrovská, H., Duthie, S., Fillion, L., Panayiotidis, M., Raslová, K. and Vaughan, N. (1997). Comet assay in human biomonitoring studies: reliability, validation, and applications. Environ. Mol. Mutagen. 30: 139-146.

Farbairn, D.W., Olive, P.L. and O'Neill, K.L. (1995). The comet assay: a comprehensive review. Mut. Res. 339: 37-59.

Freitas, T.R.O. (1995). Geographic distribution and conservation of four species of the genus Ctenomys in Southern Brazil. Stud. Neotrop. Fauna Environ. 30: 53-59.

Freitas, T.R.O. and Lessa, E.P. (1984). Cytogenetics and morphology of Ctenomys torquatus (Rodentia: Octodontidae). J. Mammal. 65: 637-642.

Hartmann, A. and Speit, G. (1995). Genotoxic effects of chemicals in the single cell gel (SCG) test with human blood cells in relation to the induction of sister-chromatid exchanges (SCE). Mut. Res. 346: 49-56.

Klaude, M., Eriksson, S., Nygren, J. and Ahnström, G. (1996). The comet assay: mechanisms and technical considerations. Mut. Res. 363: 89-96.

McKelvey-Martin, V.J., Green, M.H.L., Schmezer, P., Pool-Zobel, B.L., De Méo, M.P. and Collins, A. (1993). The single cell gel electrophore- 
sis assay (comet assay): a European review. Mut. Res. 288: 47-63.

Nascinbeni, B., Phillips, M.D., Croom, D.K., Andrews, P.W., Tice, R.R. and Nauman, C.H. (1991). Evaluation of DNA damage in golden mice (Ochrotomys nuttalli) inhabiting a hazardous waste site. Environ. Mol. Mutagen. 17: 55 (Abstract).

Olive, P.L., Wlodek, D., Durand, R.E. and Banáth, J.P. (1992). Factors influencing DNA migration from individual cells subjected to gel electrophoresis. Exp. Cell Res. 198: 259-267.

Olive, P., Frazer, G. and Banáth, J.P. (1993). Radiation-induced apoptosis measured in TK6 human B lymphoblast cells using the comet assay. Radiat. Res. 136: 130-136.

Pandrangi, R., Petras, M., Ralph, S. and Vrzoc, M. (1995). Alkaline single cell gel (comet) assay and genotoxicity monitoring using bullheads and carp. Environ. Mol. Mutagen. 26: 345-356.

Petras, M., Vrzoc, M., Pandrangi, R., Ralph, S. and Perry, K. (1995). Biological monitoring of environmental genotoxicity in southwestern Ontario. In: Biomonitors and Biomarkers as Indicators of Environmental Change (Butterworth, B.E., Corkum, L.D. and Guzmán-Rincón, J., eds.). Plenum Press, New York, pp. 115-137.

Ralph, S., Petras, M., Pandrangi, R. and Vrzoc, M. (1997). Alkaline single cell gel (comet) assay and genotoxicity monitoring using two species of tadpoles. Environ. Mol. Mutagen. 28: 112-120.

Salagovic, J., Gilles, J., Veschaeve, L. and Kalina, I. (1996). The comet assay for the detection of genotoxic damage in the earthworms: a promising tool for assessing the biological hazards of polluted sites. Folia Biol. 42: 17-21.

Sasaki, Y.F., Izumiyama, F., Nishidate, E., Ishibashi, S., Tsuda, S., Matsusaka, N., Asano, N., Saotome, K., Sofuni, T. and Hayashi, M. (1997a). Detection of genotoxicity of polluted sea water using shell- fish and the alkaline single-cell gel electrophoresis (SCE) assay: a preliminary study. Mut. Res. 393: 133-139.

Sasaki, Y.F., Nishidate, E., Izumiyama, F., Matsusaka, N. and Tsuda, S. (1997b). Simple detection of chemical mutagens by the alkaline singlecell gel electrophoresis (comet) assay in multiple mouse organs (liver, lung, spleen, kidney, and bone marrow). Mut. Res. 391: 215-231.

Singh, N.P. and Stephens, R.E. (1996). Microgel electrophoresis: sensitivity, mechanisms, and DNA electrostretching. Mut. Res. 383: 167175

Singh, N.P., McCoy, M.T., Tice, R.R. and Schneider, E.L. (1988). A simple technique for quantification of low levels of DNA damage in individual cells. Exp. Cell Res. 175: 184-191.

Speit, G. and Hartmann, A. (1996). Nachweis von genotoxischen Unweltschadstoffen mit dem "Comet Assay". In: Landesanstalf für Unweltschutz Baden-Württemberg (Projekt, Angew an dte Ökologie). Ulm, pp. 114.

Srám, R.J., Holá, N., Kotesovec, F. and V’Ávra, R. (1985). Chromosomal abnormalities in soft coal open-cast mining workers. Mut. Res. 144: 271-275.

Tice, R.R. (1995). Applications of the single cell gel assay to environmental biomonitoring for genotoxic pollutants. In: Biomonitors and Biomarkers as Indicators of Environmental Change (Butterworth, B.E., Corkum, L.D. and Guzmán-Rincón, J., eds.). Plenum Press, New York, pp. 69-79.

Verschaeve, L. and Gilles, J. (1995). Single cell gel electrophoresis assay in the earthworm for the detection of genotoxic compounds in soils. Bull. Environ. Contam. Toxicol. 54: 112-119.

(Received November 26, 1998) 
